\title{
Using a translanguaging approach in teaching paraphrasing to enhance reading comprehension in first-year students
}

Author:
Vimbai Hungwe ${ }^{1}$ (
Affiliation:
'Department of Language
Proficiency, Sefako Magatho
University, Pretoria,
South Africa
Corresponding author:
Vimbai Hungwe,
vimbai.hungwe@smu.ac.za
Dates:
Received: 07 Sept. 2018
Accepted: 02 Apr. 2019
Published: 27 June 2019
How to cite this article:
Hungwe, V., 2019, 'Using a
translanguaging approach
in teaching paraphrasing
to enhance reading
compreade device
to read online.
students', Reading \& Writing
10(1), a216. https://doi.org/
10.4102/rw.v10i1.216
Copyright:
C 2019. The Authors.
Licensee: AOSIS. This work
is licensed under the
Creative Commons
Attribution License.

Background: The teaching of reading strategies that enhance comprehension is a priority for many practising lecturers involved in academic literacy programmes. However, due to the unprepared nature of a large section of students entering the Higher Education system, a number of students have been found to lack basic literacy skills such as reading for comprehension. A plethora of studies has been conducted locally and internationally with the aim of finding solutions to help students who struggle with text comprehension, especially at university level.

Objectives: The purpose of this research is to show how paraphrasing as a strategy can be combined with a translingual approach to instruct students explicitly on how to read and comprehend texts

Method: Using a group of first-year multilingual medical students, this research included translanguaging as an additional component to the use of paraphrasing as a reading comprehension strategy.

Results: The paper provides insight into how translanguaging can be used to assist multilingual students to understand texts through paraphrasing. Drawing empirical data from classroom activities, this paper shows how lecturers can help students to use translanguaging and paraphrasing as metacognitive strategies to help improve their comprehension of texts.

Conclusion: Finally, the importance of allowing students to utilise their multilingual repertoires is emphasised and reiterated, through translanguaging, in order to enhance learning.

Keywords: Paraphrasing; translanguaging; reading comprehension; multilingualism; multilingual education.

\section{Introduction}

Reading is an important skill required for many academic activities (Hagaman, Casey \& Reid 2012), especially at university level. However, recent assessments of reading skills locally and internationally show that reading comprehension among students is still of great concern. In the United States, about a third of Grade 4 pupils are able to read and understand texts fully (Hagaman et al. 2012). In South Africa, too, a variety of factors contribute to poor reading comprehension among students. According to Currin and Pretorius (2010), poor teaching methods at school level is one of the major factors that hinder reading development in many students. Many of the students who struggle to comprehend texts especially at university may have attended schools where very little emphasis was placed on reading and writing in English (Probyn 2006; Taylor \& Vinjevold 1999). In addition, many of the students also find reading in English difficult because it is a second (L2) or third language to them (Ngcobo 2014).

When all explanations for poor reading comprehension in especially university students are considered, there is evidence that reading comprehension is a serious problem among many students (Underwood \& Pearson 2004). These problems stem from inadequate reading instruction at a very basic level of education. The identification of the problem certainly means there is a need for teachers to improve their teaching methods in order to improve students' reading comprehension skills. Several studies (Brown \& Palincsar 1989; Graham \& Bellert 2004; Pressley 2000; Pressley \& McCormick 1995) have shown that, in order for students to understand texts, teachers explicitly need to teach comprehension skills.

According to Grabe and Stoller (2011), it is not necessary for academic literacy courses at university to include extensive grammar review; although grammatical errors should not be ignored as a 
resource for more advanced comprehension abilities. Rather, it is suggested that the main idea of the text should be at the heart of L2 reading instruction. Grabe and Stoller (2011) suggest that the main idea of a text can be understood through class conversations that encourage identifying and exploring main ideas, as well as building connections between the text and student background knowledge. In the same sense, L2 students can be assisted to build text structure awareness to enhance their reading comprehension. Ultimately, students should be encouraged to explain main ideas to each other in group collaboration activities using their own languages.

The ability to extrapolate and paraphrase main ideas from the text constitutes the meaning-making process, which is the comprehension process that is required when reading (King 2007). However, there are different levels of comprehension. Deep comprehension is achieved when a reader progresses beyond literal comprehension to using the text combined with prior knowledge to construct understanding. Unfortunately, according to King (2007), most students rarely gain a deep understanding of the materials they read in their course. Instead, they settle for shallow knowledge such as listing facts, definitions and other memorised material. In fact, students need to organise shallow knowledge and go beyond it by pursuing deep explanations, causes and implications.

King (2007) emphasises the importance of inference during and after reading in order to enhance understanding. King's argument comes from the fact that in most cases writers leave some information implicit in their text, with the assumption that the reader will infer from the text. Unfortunately, many readers are not able to infer meaning from texts. This is one reason why most readers cannot move from a shallow understanding of texts to a deeper understanding.

It is important to note, however, that there is a gap between what research has found and what is being practised in the classroom. Many students gain university entrance without the foundational skills required for them to fully read and comprehend texts. This militates against their success at university.

The purpose of this research is to show how paraphrasing as a strategy can be combined with a translingual approach to instruct students explicitly on how to read and comprehend texts.

\section{Related literature}

According to Fisk and Hurst (2003), paraphrasing is an excellent tool for reinforcing reading skills such as identifying main ideas, finding supporting details and identifying the author's details. Hirvela and Du (2013) identify paraphrasing as a principal means by which students can demonstrate their understanding of texts by capturing the original ideas of the author using their own words. In as much as paraphrasing has been identified as a barometer to measure students' reading comprehension skills, it is unfortunate that there is a dearth of both pedagogical and research literature corroborating the importance of using paraphrasing as a tool to enhance reading comprehension. According to Hyland (2001), a major reason for this scarcity is that paraphrasing is often subsumed by summary writing.

Hedgecock and Ferries (2009:185) distinguish summarising from paraphrasing by stating that a summary is always shorter than the original material. A paraphrase is also written in the student's own words, but it is a restatement of the original information and is therefore as long (or longer) than the original material. A summary is based primarily on main ideas, while a paraphrase includes all details from the text using different words. According to Yamada (2003), paraphrasing is a process or set of processes in which students are required to engage in acts such as inferential thinking and decision-making as they generate meaningful and accurate reconstructions of what they have read.

Paraphrasing is an active learning strategy which helps students to place information into long-term memory as they move from an understanding level to an active comprehension level. According to Fisk and Hurst (2003), paraphrasing works very well as a tool to enhance comprehension because it integrates all modes of communication, i.e. reading, writing, listening and speaking, which leads to a deeper understanding of the text. Leamnson (1999) also contends that there is no better way to learn content from a text, lecture or discussion than to paraphrase. Thus, paraphrasing is an integral tool that is essential in tackling the reading comprehension challenges faced by students.

An important marker of a student's understanding of a text is the ability to find new ways to capture the meaning of what was stated in the passage (Hirvela \& Du 2013). Research has shown that many students, especially L2 students, struggle to paraphrase because they feel that they cannot compete with the experts' language, therefore they resort to copying word for word from the text without much comprehension (Hyland 2001). Thus, it is important to mention the practical ways in which paraphrasing can be used to benefit students who struggle to comprehend texts. According to Harvey and Goudvis (2000), paraphrasing can be used during collaborative activities. In fact, when students are allowed to interact with one another and to challenge each other's ideas, higher level thinking is the ultimate result.

As early as the 1990s, Harris and Sipay (1990) discovered that when students are allowed to express the author's ideas in their own languages clearly and unambiguously, it shows that ideas from the texts were understood. Thus, paraphrasing can be used in multilingual classrooms by allowing students to write ideas from a text in their first language (L1) as a test for comprehension. Although Harris and Sipay (1990) do not provide a name for the process of expressing the author's ideas in one's language for deeper understanding, that process is now referred to as translanguaging. 


\section{Theoretical framework}

This study is premised on the translanguaging paradigm. Williams (1996), who coined the term translanguaging, defines it as a bilingual pedagogy that alternates language modes. The input is in one language while the output is in the other language. Translanguaging as pedagogy was initially related to bilingual education and refers to 'building bilingual students' language practices flexibly in order to develop new understandings and new language practices' (Garcia, Flores \& Woodley 2012:52).

Canagarajah (2011) purports that, in multilingual environments, translanguaging takes place when students use their entire linguistic repertoire strategically to learn. Baker (2011) refers to translanguaging as the use of two languages to make meaning, gain understanding and gain knowledge. However, according to Garcia and Wei (2014), translanguaging does not refer to two separate language practices or to a hybrid mixture of languages; instead, it refers to a single linguistic repertoire.

Garcia and Wei (2014) premise translanguaging within the recent critical post-structural paradigm shift in applied linguistics. Proponents of this school of thought (Garcia \& Wei 2014; Makalela 2016; Makoni \& Pennycook 2007; May 2014; Ndlhovu 2017) question the notion of languages being separate and disconnected entities. The paradigm questions the homogeneity, boundedness and stability of languages in favour of mobility, mixing and historical embedding in the study of language (Blommaert \& Rampton 2011). As a result, Garcia and Wei (2014) view translanguaging as a new language practice which emerges from exchanges among people with different histories that were created by the compartmentalisation of languages due to nation-building. In fact, according to Wei (2016), translanguaging is a process that transcends the notion of movement between languages.

Translanguaging allows bilinguals to deploy their full linguistic repertoire, disregarding adherence to the socially and politically defined boundaries of named languages (Otheguy, Garcia \& Reid 2015). That is why Garcia and Leiva (2014:204) insist that translanguaging resists the historical and cultural 'positionings' of monolingualism and advocates for fluid and fuzzy boundaries between languages in order to promote social justice. This research is based on the critical post-structural paradigm in which all languages within multilinguals' repertoires are allowed to manifest for deeper understanding and for meaning-making processes to take place. Instead of treating languages as separate entities in order to understand texts, this paper argues that students should be allowed to use all the languages at their disposal to understand texts.

In the case of Africa, Makalela (2016) asserts that languages were put in 'boxes' as a way for political leaders to promote national sovereignty. Makalela, therefore, calls for a multilingual return by articulating the interconnectedness of African languages in the Mapungubwe settlement of the $10^{\text {th }}$ century. Makalela emphasises that what guided these people was a worldview of belonging together (ubuntu) despite differences. Thus, in the classroom, Makalela advocates for the Ubuntu Translanguaging Pedagogy (UTP), where students use their various linguistic resources to understand texts.

Based on the critical post-structuralist paradigm in which translanguaging is premised, languages have no boundaries and are not compartmentalised. This, therefore, should prompt lecturers to adopt a translanguaging model of teaching reading comprehension by allowing students to utilise all the linguistic resources at their disposal. This paper argues that students enter classrooms with rich linguistic repertoires (Carroll \& Morales 2016) that require recognition and utilisation for meaning-making and understanding of the reading material. The call to recognise, value and utilise students' linguistic repertoires is emphasised by Garcia and Kleyn's (2016) call for educators to start looking at language from the point of view of the multilingual students in their classrooms. In the same vein, Mgijima and Makalela (2016) argue for a literacy model that integrates learners' linguistic repertoires in order to enhance reading development at an elementary level.

My argument is based on the contention of Lewis, Jones and Baker (2012) that the use of one language through translanguaging helps to develop the other. In addition, the targeted use of students' L1 helps students to understand the meaning of new and difficult words and explains complex syntactic rules (Hussein 2013). Storch and Wigglesworth (2003) conclude that when L1 is used in an English as a Second Language (ESL) classroom, learners receive additional cognitive support that allows them to work at a higher cognitive level than they would be if they were restricted to the sole use of their L2. In order for students to gain a full understanding of the texts that they read, I argue that translanguaging involves reading the text in a target language (English in this case) while discussing and writing the content in a combination of both target and home languages. This paper intends to show that, in addition to using paraphrasing as a measure for comprehension of texts, translanguaging should be incorporated for pedagogical purposes. This paper presents translanguaging and paraphrasing as pedagogical tools that enhance reading comprehension in students.

\section{Methodology Research context}

The findings of this article are based on a study conducted to investigate the effectiveness of using translanguaging and paraphrasing as tools to enhance reading comprehension in first-year medical students. The study was conducted at a university in South Africa where most of the students are multilingual and English is not yet adequately developed for academic purposes. The languages spoken by the majority of students at this university are Sepedi, Setswana, 
Afrikaans and Tshivenda. Many of these students struggle to comprehend academic texts that they are expected to read. This has been a cause for concern at this institution.

The Department of Language Proficiency (DLP) was established with the sole responsibility of servicing all health science departments with the required English language proficiency in their fields of study. Thus, the DLP services the following departments: Pharmacy, Medicine, Dentistry, Physiotherapy, Radiography, Speech Therapy, Occupational Therapy, and Nursing. Lecturers from these departments have registered complaints to the DLP about students struggling to comprehend academic texts. As a lecturer in the DLP, I decided to embark on this inquiry using translanguaging as a strategy and teaching resource to help students develop metacognitive skills that will assist them in tackling reading comprehension challenges. Ethical clearance was granted by the university's ethics clearance committee.

\section{Research design}

The research design for the study is mainly qualitative, using excerpts from students' writing as data.

\section{Participants}

Participants in this research were first-year students studying medicine. A convenience sampling method was used to select the participants. According to Saunders, Lewis and Thornhill (2012), convenience sampling (also known as availability sampling) is a specific method that relies on data collection from population members who are conveniently available to participate in the study. In the case of this research, participants were selected on the basis of them having been allocated to me as their lecturer. The participants were 36 first-year medical students. The mean age of this group was 19 years. Of the 36 students, 20 were male and 16 female. As mentioned earlier, these students are not L1 speakers of English.

\section{Data collection}

Data were collected during lecture time. Participants were divided into discussion groups of six and were required to read an academic text entitled 'In search of the Holy Grail' ${ }^{1}$ individually, outside of class. Dividing students into discussion groups is a strategy recommended by Harvey and Goudvis (2000) to help students better understand texts. In order to maintain the fluid nature of languages, participants were allocated to groups where members spoke different languages.

The article they read reports on the Human Genome Project in the UK. This scientific project aims to design human genes so that in future humans are born free of certain diseases and ailments caused by genes that they might have inherited from their parents. The project aims to study the human genome, derive mechanisms to alter people's genetic 1.Available from http://mini-ielts.com/139/reading/in-search-of-the-holy-grail inheritance and design the ideal genetic makeup - free from genetically inherited diseases such as cancer, cystic fibrosis, heart disease etc. This article was recommended for these students' main field of study, which is medicine.

When participants came to class, they were required to discuss the ideas of the text, using all the languages at their disposal, that is, translanguaging. This included discussing unfamiliar words and using the dictionary to look up meanings in their languages. Each group was asked to split into two groups of three students. One group of three was supposed to write a paraphrase of the author's ideas in English using their own words. The other three had to write the ideas in their home language(s). Finally, they had to come together as a group of six and discuss (in any of the languages they felt comfortable with) and finally fuse their paraphrases to present the ideas of the paragraph.

The main aim of this research was to avoid forcing the students to think and understand the article in English. Rather, the participants were allowed to explore the fluid and fuzzy boundaries of languages (Garcia \& Leiva 2014) by utilising all languages at their disposal as they tried to negotiate and grasp the meaning of the text. In addition, students could measure their understanding of the text as they moved and shuffled between the languages at their disposal (Harris \& Sipay 1990). Students were instructed to pick one paragraph of their choice from the text and convey the meaning of the paragraph through paraphrase.

\section{Data analysis}

This research employed a language-oriented analysis (Tesch 1991:17-25). This analysis is primarily interested in the use of language and the meaning of words. Based on this analysis, excerpts of the draft paraphrases were analysed with specific attention to the way participants negotiated their understanding of the text using their linguistic resources until they could put it on paper. The final versions of the paraphrases were analysed to see if participants were able to use their own vocabulary and phrases to present the ideas of the text. Particular focus was placed on determining whether students were able to refrain from copying from the original text. According to Hirvela and Du (2013), when students use their own words to state the main ideas of the text, it shows some understanding of the reading material. Another focus was to see if students could use their experiences from their language practices to understand the text.

\section{Ethical consideration}

The research went through the required ethics clearance process.

\section{Results}

Having read the article, students stated that the article was just too difficult for them to understand. They indicated that the title itself (In search of the Holy Grail) appeared unrelated 
to the article's subject matter. When asked to look up 'holy grail' in their dictionaries, students indicated that the dictionary defined the Holy Grail as the cup that Jesus drank from during his last supper with his disciples. They could not make the connection between the Holy Grail (the cup) and the human genome. This is because the meaning was inferential and required students to infer meaning to understand the text (King 2007). Through discussion, the meaning was negotiated until students could understand that the expression 'Holy Grail' refers to something that is difficult to obtain.

As a lecturer to multilingual students, I cannot speak all their languages. I used simple English terms to explain the title. In order to connect with the text, during the discussion, I paralleled the title 'searching for the Holy Grail' to a familiar saying: 'looking for a needle in a haystack'. Then I asked students to relate the explanation in their own languages so that they could understand it better. Establishing this parallel helped students to understand the title of the article because they were able to come up with common sayings in Sepedi and Setswana which mean the same as 'in search of the Holy Grail': Moleta ngwedi ke moleta lefifi in Setswana and Moleta ngwedi ke moleta leswiswi in Sepedi. Both sayings, when literally translated, mean that when it is dark you cannot see the moon, no matter how much you look for it. When students applied their cultural and language background, they could understand the title of the article. The use of relevant background to infer meaning is emphasised by Mgijima and Makalela (2016) as a vehicle for improving reading comprehension. In fact, students need to be taught from an early age to infer meaning from texts using all the accessible linguistic resources at their disposal (Mgijima \& Makalela 2016). In this study too, by allowing students to use their rich linguistic and cultural backgrounds, they were able to understand the title of the article, which in turn helped them to understand the article too. Through this process, students were able to understand that the title of the article was a metaphor used to show that the Human Genome Project was attempting a difficult task.

The encouragement during class discussion to use their linguistic and cultural background helped the students to grasp the general meaning of the article. The use of a familiar saying (Looking for a needle in a haystack) as well as the common Sepedi and Setswana sayings helped them to break through the barrier that had been created by the phrase 'In search of the Holy Grail' and allowed them to utilise their linguistically and culturally pre-existing knowledge to scaffold their understanding of the text.

Results from this research show that students indeed face a mammoth task of working out meaning, especially when they are faced with unfamiliar contexts. In fact, participants in this study demonstrated a shallow understanding of the text. The fact that they could not make a connection between the title and the meaning of the text shows what King (2007) refers to as shallow comprehension. However, through collaboration and discussion using students' language practices (Grabe \& Stoller 2011), students gained a deep understanding of the texts. It is important for lecturers, therefore, to help students gain a deeper understanding of a text by using a translingual approach to collaboration in class discussions. Most importantly, allowing students to understand difficult and unfamiliar terms using their linguistic resources enhances their understanding of the target language (Hussein 2013).

\section{Paraphrases}

Students were instructed to choose a paragraph from the article and paraphrase it. Each group produced paraphrases that were written in the languages spoken by group members as well as an English version which was a fusion of the ideas in the different languages. The results were as follows:

\section{Paragraph 3}

Three groups chose to paraphrase paragraph 3 but for purposes of this paper paraphrases from two groups will be discussed. This paragraph provides an explanation of how a baby inherits certain genes from its parents. It further explains that the human genome is a complex phenomenon which is written in chemical letters amounting to 3 billion and that it takes a decade to track down, analyse and record one genetic letter. In a nutshell, the paragraph shows that human DNA is a complex phenomenon which is extremely difficult to understand.

Generally, students were able to paraphrase the paragraph using their own words without altering its meaning. Worth noting is that, as students used their own languages to paraphrase, there was no attempt to translate from English. This suggests the interconnectedness of languages - students did not need to translate from one language to the other; rather, meaning was conveyed without translation. As noticed in the paraphrases, students did not use direct translation of the text that they had read; rather, they used their understanding of the text using their various linguistic resources. For example, one group used Tshivenda and English in their discussions (see Figure 1).

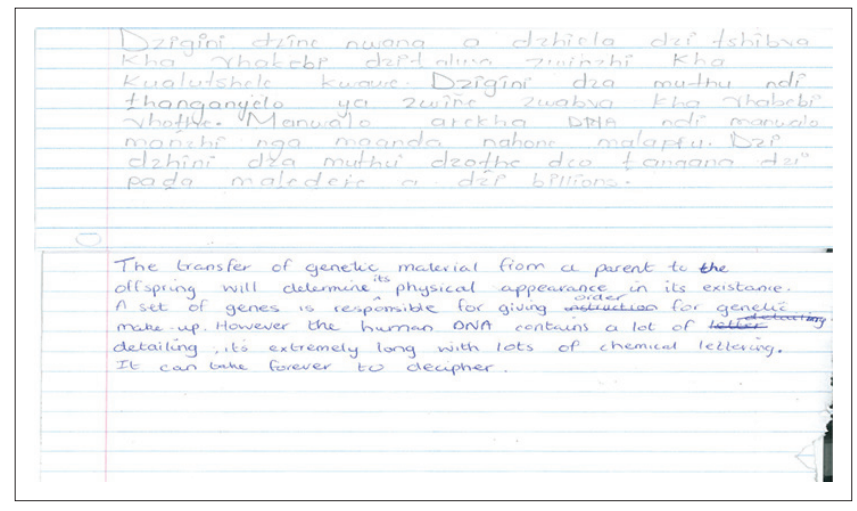

FIGURE 1: Excerpt 1. 
Based on the paraphrase written by this group, there is a general understanding of the passage. The word 'inheritance' in the original passage, however, was replaced by the word 'transfer' in the paraphrase. The ability to replace words with synonyms is a measure of comprehension (Fisk \& Hurst 2003). However, it is important to mention that this group's Tshivenda paraphrase sufficiently conveys the meaning of the original paragraph. Although participants could not find the synonym for 'inheritance' in their language, they used the phrase 'Dzigini dzine nwana' to mean the features that a child is born with. This phrase conveys the idea of a baby's genetic inheritance from its parents.

The original passage outlines the fact that tracing the 'unwanted' genes inherited from parents is a difficult task, considering the effort and time required to read and flush out a single gene from a huge genetic text of over 3 billion chemical letters. This idea is clearly conveyed in both the English and Tshivenda paraphrases. In the English paraphrase, the students capture the complex nature of the human DNA by stating: ' ... the human DNA contains a lot of detailing, it's extremely long with lots of chemical lettering'. Similarly, the Tshivenda version captures the meaning of the text quite remarkably: 'Manwalo [letters] arekha DNA ndimanwalo manzhi [many letters]'.

The fact that students used their understanding of the text and were able to convey the meaning in their language (Tshivenda) and successfully convey the same meaning in English proves the fluidity and interconnectedness of languages. The problem is that the education system thrives on putting languages into compartments to avoid mental confusion (Makalela 2015, 2016) and emphasises the monolingual use of English for pedagogical purposes. From a translanguaging point of view that is propelled in the critical post-structural shift paradigm, however, languages were created for demarcation and sovereign purposes (Makalela 2015). That is to say, languages were separated in order to separate people from each other for political reasons. In fact, languages are fluid and have no boundaries. Thus, there is no reason to insist on using one language for pedagogical purposes when meaning-making and understanding of texts can be achieved in any language at the student's disposal.

The results presented in this paper suggest a rich and deep understanding of text when input (Baker 2011) is in English, successful meaning can be made using the home language and output (Baker 2011) is in English. Also, when students are allowed to utilise accessible linguistic repertoires, their reading comprehension will be enhanced (Mgijima \& Makalela 2016). There is a need for teachers to create translanguaging classrooms (Garcia, Johnson \& Seltzer 2016) in order to help students to understand and grasp the deeper meaning of the texts they encounter in their academic endeavours.

Another group also chose to paraphrase paragraph 3. This group, however, indicated that they could only use English

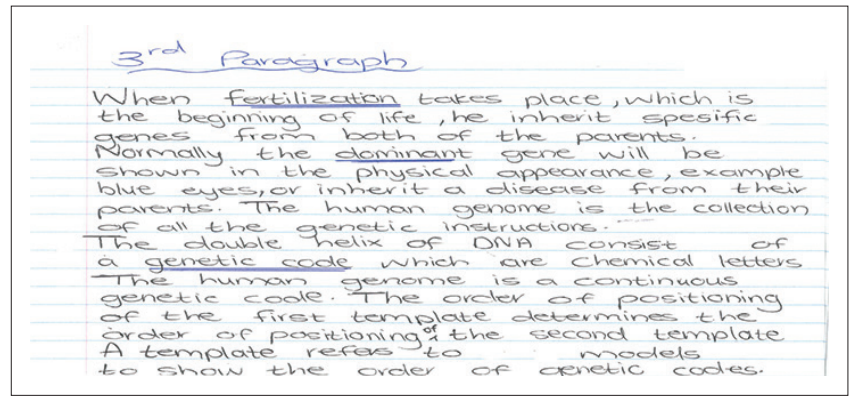

FIGURE 2: Excerpt 2.

to discuss and write their paraphrase. The students maintained that they had attended schools where English was the only medium of instruction. These students also indicated that it was impossible to use any other language for learning besides English. They argued that the text they had read was in English, therefore, they felt comfortable discussing and writing in English. In order to establish how well the students would perform in their paraphrase, I allowed them to use English only (see Figure 2).

This group failed to show that they had understood the meaning of the text. As mentioned earlier, the paragraph intended to prove that studying human DNA is a complex process because the DNA text contains a great number of chemical letters. Instead, the group defines the genetic codes and they refer to genetic templates. Ultimately, this group failed to interpret the meaning of the paragraph and they introduced new information which is not related to the meaning of the paragraph. The reason for this group's failure to understand and grasp the meaning of the text cannot be speculated on. However, Rivera and Mazak (2016) explain that it may be difficult for students who treat languages as unique and separate entities to break free from this ideology. It is important, therefore, to research this issue further and find ways of changing such students' attitude towards translanguaging.

\section{Paragraph 7}

Two groups chose to paraphrase paragraph 7 of the article and both groups used Sepedi and English to convey their understanding of this paragraph. One group comprised of two Sepedi speakers and one speaker each of Tshivenda, Setswana, siSwati and Xitsonga. Due to the linguistically heterogeneous nature of the group, they decided to use Sepedi for their paraphrase. Observation of this group's discussion showed that participants used all the languages spoken by group members to negotiate meaning. It should be noted that there was a mutual understanding of meaning as all members of the group contributed to the discussion. In addition, some participants also used English to explain some concepts among them as they negotiated meaning. I emphasise that a translanguaging approach does not eliminate English from being utilised for meaning-making. English contributes to the students' linguistic repertoires and can be used as needed for meaning-making and a deeper understanding of concepts. 


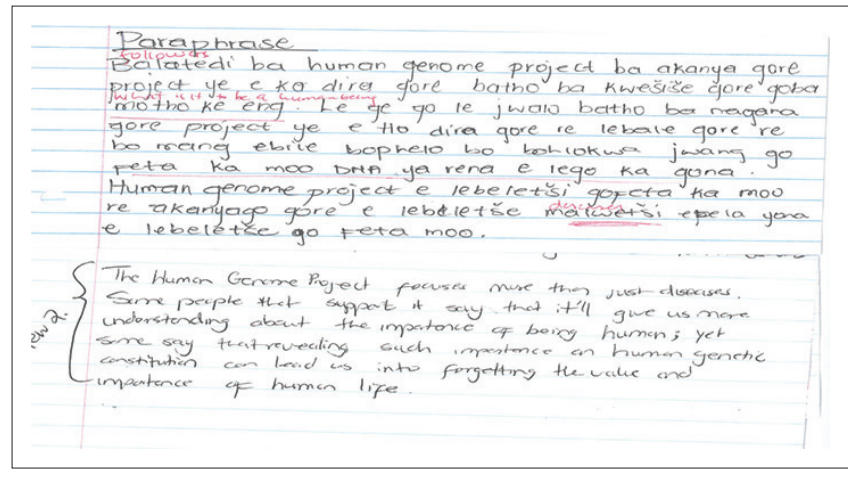

FIGURE 3: Excerpt 3.

Paragraph 7 presents arguments against the Human Genome Project. The paragraph argues that, although the project might bring people to understand more about what it is to be human, too much focus on humans' genetic constitution may result in people forgetting that there is more to human life than the expression of the chemistry of DNA.

Using Sepedi and English, this group was able to negotiate the meaning of the paragraph and convey it in the paraphrase (see Figure 3).

The Sepedi version highlights the fact the Human Genome Project is important because it will help people to understand human genetic makeup. This is captured in the phrase: '... project ye e kadira gore bathobakwesise gore gobamothokeeng'. This is also highlighted in the English version, which mentions that the project does not only focus on avoiding genetically inherited disease but also helps people to understand the importance of being human. The paraphrase also refers to the fact that critics of the Human Genome Project warn that too much emphasis on human DNA might lead people to forget the importance of valuing human life. In Sepedi, they wrote: '... batho ba nagana gore project ye e tlo dira gore re lebale gore re bo mang ebile ...'.

In general, both the Sepedi and English paraphrases capture the intended meaning of the paragraph.

\section{Discussion}

The purpose of this paper is to affirm that translanguaging can be used as a pedagogic strategy to enhance comprehension of academic texts. The research uses paraphrasing and translanguaging as useful tools to gauge comprehension of reading material. The results have shown the importance of adopting a multilingual approach to language teaching. The fact that participants in this research were able to produce paraphrases in two languages and retain meaning in both languages proves that languages can be used interchangeably and fluidly by students for meaning-making and a deep understanding of texts. It is important to note that both the Sepedi and Tshivenda paraphrases did not in any way attempt to translate English to Sepedi or Tshivenda and back to English in order to convey the same meaning. Students were able to draw their meaning from different languages at their disposal. This proves the fluidity and interconnectedness of languages, thus affirming the need to transcend language boundaries (Garcia \& Wei 2014; Wei 2016; Makalela 2016) and allow students to utilise all languages for meaning-making.

Lecturers should consider seriously Makalela's (2016) call for a multilingual return. As mentioned before, one of the groups decided to write their paraphrases in Sepedi and English although the group comprised of members who speak other languages too. Hence, they were able to coordinate and collaborate harmoniously using all the languages at their disposal. This proves the need to incorporate the UTP, where multilingual classrooms become havens of fluid, unbounded and interdependent repertoires through which students make meaning of the academic material through collaboration (Makalela 2016). The UTP proves the possibility of a multilingual return where students can be allowed to utilise their entire linguistic repertoire during collaboration in order to achieve a common goal.

It is important to note that the use of translanguaging provides a 'haven' for multilingual students to negotiate the meaning of English texts. The level of comprehension displayed by these students confirms Harris and Sipay's (1990) assertion that when students are allowed to express what they have read in their own languages (translanguaging) it suggests that they have understood the text. Thus, I urge all teachers and lecturers to transcend linguistic boundaries (Wei 2016) and allow the fluidity of languages in their classrooms to enable meaning-making and deeper understanding of texts. Lecturers must create an instructional space where translanguaging is nurtured without students having to suppress their linguistic repertoire (Garcia \& Lin 2017). Thus, a classroom where students manifest and utilise their linguistic repertoires constitutes a 'haven' for students to attain a deeper understanding of the learned material.

The fact that I, as the lecturer, do not speak all the languages spoken by my students did not dissuade me from allowing and encouraging students to utilise their linguistic resources in order to gain a deeper understanding of the text. In order to assist students in understanding the text, I allowed them to explore their ideas through the linguistic resources they possess. During class discussion, I relied mostly on students' interpretation of the title 'In search of the Holy Grail' in their languages. This is in line with Garcia and Lin's (2017) call for teachers to create space in the classroom for students to utilise features of their linguistic repertoires as they negotiate meaning. It also concurs with Makalela's (2016) research during which he created space for understanding among his multilingual students by allowing them to use their different language repertoires. In addition, Essien (2010) refers to the acknowledgement, recognition and utilisation of linguistic metaphors prevalent among multilingual students as one of the best practices that teachers need to inculcate in their students. 
It can be suggested that students need to be taught the need to infer the meaning of texts using their relevant linguistic repertoires from an elementary level (Mgijima \& Makalela 2016). If students learn to utilise their full linguistic repertoires to grasp the meaning of texts, they will not struggle when they reach university, because the skill would have been learned at an early stage of their academic career.

\section{Conclusion}

Grounded in the critical post-structural shift paradigm which translanguaging emanates from, this paper has provided evidence to show the importance of cultivating and encouraging students to use all the languages at their disposal for meaning-making and a deeper understanding of texts. Paraphrasing is a tool that can be used together with a translingual approach to help students grasp the meaning of texts. The results show that when students are accorded the opportunity to freely utilise the linguistic resources at their disposal, they are able to comprehend texts. It is also important to mention that although participants in this research used a translingual approach to help them understand the article, they eventually were able to produce paraphrases in English that showed that they had understood the paragraphs that they paraphrased. This confirms that the use of more than one language enhances understanding as opposed to causing confusion in students' minds. I, therefore, recommend that lecturers employ a translanguaging strategy in their classrooms to help students understand texts. I further recommend that lecturers create a 'haven' in classrooms by employing translanguaging pedagogy. It is also important for lecturers to introduce different learning strategies that will help students to understand texts; this includes the use of translanguaging. Insisting on the monolingual use of English in the classroom may not solve the problem of poor comprehension among students. Lastly, further research is recommended to find ways of helping students who insist on using English only for meaning-making, although they struggle to comprehend English texts.

\section{Acknowledgements}

The author would like to thank the research participants.

\section{Competing interests}

The author declares that he has no financial or personal relationships which may have inappropriately influenced him in writing this article.

\section{References}

Baker, C., 2011, Foundations of bilingual education and bilingualism, Multilingual Matters, Bristol.

Blommaert, J. \& Rampton, B., 2011, 'Language and super-diversity', Diversities 13(2), 1-19.

Brown, A. \& Palincsar, A., 1989, 'Guided cooperative learning and individual knowledge acquisition', in L. Resnick (ed.), Knowing, learning and instruction: Essays in honour of Robert Glaser, pp. 393-451, Lawrence Erlbaum, Hillsdale.

Canagarajah, S., 2011, 'Translanguaging in the classroom: Emerging issues for research and pedagogy', Applied Linguistics Review 2, 1-27.
Carroll, K.S. \& Morales, A.N.S., 2016, 'Using university students' L1 as a resource: Translanguaging in a Puerto Rican ESL classroom', Bilingual Research Journal 39(3), 248-268. https://doi.org/10.1080/15235882.2016.1240114

Currin, S. \& Pretorius, E.J., 2010, 'The culture of the sharp pencil: Can a literacy intervention lever school change?', Reading and Writing 1(1), 23-46.

Essien, A., 2010, 'What teacher educators consider as best practices in preparing preservice teachers for teaching Mathematics in multilingual practices', Perspectives in Education 28(4), 32-42.

Fisk, C. \& Hurst, B., 2003, 'Paraphrasing and comprehension', The Reading Teacher 57(2), 182-185.

Garcia, O., Flores, N. \& Woodley, H., 2012, 'Transgressing monolingualism and bilingua dualities: Translanguaging pedagogies', in A. Yiakoumetti (ed.), Harnessing linguistic variation to improve education, pp. 45-76, Peter Lang, Bern.

Garcia, O., Johnson, S.I. \& Seltzer, K., 2016, The translanguaging classroom: Leveraging student bilingualism for learning, Carlson, Philadelphia.

Garcia, O. \& Kleyn, T., 2016, 'Translanguaging theory and project', in O. Garcia \& T. Kleyn (eds.), Translanguaging with multilingual students: Learning from classroom moments, pp. 9-34, Routledge, New York.

Garcia, O. \& Leiva, C., 2014, 'Theorizing and enacting translanguaging for social justice', in A. Blackledge \& A. Creese (eds.), Heteroglossia as practice and pedagogy, pp. 199-216, Springer, New York.

Garcia, O. \& Wei, L., 2014, Translanguaging language, bilingualism and education, Palgrave Macmillan, New York.

Garcia, O. \& Lin, A.M.Y., 2017, 'Translanguaging in bilingual education', in O. Garcia, A.M.Y. Lin \& S. May (eds.), Bilingual and multilingual education, 3rd edn., pp. 1-13, Springer International, Cham.

Grabe, W. \& Stoller, F.L., 2011, Teaching and researching reading, 2nd edn., Pearson Education, Edinburg.

Graham, L. \& Bellet, A., 2004, 'Difficulties in reading comprehension for students with difficulties', in B. Wong (ed.), Learning about learning disabilities, pp. 251-279, Elsevier, San Diego.

Hagaman, J.L., Casey, K.J. \& Reid, R., 2012, 'The effects of the paraphrasing on the reading comprehension of young students', Remedial and Special Education 33(2), 110-123. https://doi.org/10.1177/0741932510364548

Harris, A.J. \& Sipay, E.R., 1990, How to increase reading ability: A guide to developmental and remedial methods, Longman, New York.

Harvey, S. \& Goudvis, A., 2000, Strategies that work: Teaching comprehension for understanding and engagement, Stenhouse, Portland.

Hedgecock, J.S. \& Ferries, D.R., 2009, Teaching readers of English: Students, texts and contexts, 2nd edn., Lawrence Erlbaum, Mahwah.

Hirvela, A. \& Du, Q., 2013, 'Why am I paraphrasing? Undergraduate ESL writers' engagement with source-based academic writing and reading', Journal of English for Academic Purposes 12(2), 87-98. https://doi.org/10.1016/j.jeap.2012.11.005

Hussein, B., 2013, 'Teaching and learning English as a second/foreign language through mother tongue: A field study', Asian Social Science 9(10), 175-180. https://doi.org/10.5539/ass.v9n10p175

Hyland, K., 2001, Disciplinary discourses: Social interaction in academic writing, Longman, Harlow.

King, A., 2007, 'Beyond literal comprehension: A strategy to promote deep understanding of text', in S.D. McNamara (ed.), Reading comprehension strategies: Theories, interventions and technologies, pp. 267-290, Lawrence Erlbaum, New York.

Lewis, G., Jones, B. \& Baker, C., 2012, 'Translanguaging: Developing its conceptualisation and contextualisation', Educational Research and Evaluation 18(7), 655-670.

Leamnson, R., 1999, Thinking about teaching and learning: Developing habits of learning with first year college and university students, Stylus, Sterling.

Makalela, L., 2014 'Teaching indigenous African languages: The effects of translanguaging for multilingual development', in L. Hibbert \& C. van der Walt (eds.), Multilingual universities in South Africa: Reflecting society in higher education, pp. 88-104, Multilingual Matters, Bristol.

Makalela, L., 2015, 'Moving out of linguistic boxes: The effects of translanguaging strategies for multilingual classrooms', Language and Education 29(3), 200-217. https://doi.org/10.1080/09500782.2014.994524

Makalela, L., 2016, Translanguaging practices in a South African institution of higher learning: A case of Ubuntu multilingual return', in C.M. Mazak \& K.S. Carroll (eds.) Translanguaging in higher education, pp. 65-78, Multilingual Matters, Bristol.

Makoni, S. \& Pennycook, A., 2007, Disinvesting and reconstituting languages, Multilingual Matters, Clevedon, England.

May, S. (ed.), 2014, The multilingual turn: Implications for SLA, TESOL, and bilingua education, Routledge, New York.

Mgijima, V.D. \& Makalela, L., 2016, 'The effects of translanguaging on the biliterate inferencing strategies of fourth-grade learners', Perspectives in Education 34(3), 86-93. https://doi.org/10.18820/2519593X/pie.v34i3.7

Ndlhovu, F., 2017, 'Language, migration, diaspora: Challenging the big battalions of groupism', in O. Garcia, N. Flores \& M. Spotti (eds.), The Oxford handbook of language and society, pp. 141-160, Oxford University Press, New York.

Ngcobo, S., 2014, 'Dual language instruction: Its impact on attitude towards the role of African languages in education', in L. Hibbert \& C. van der Walt (eds.), Multilingua universities in South Africa: Reflecting society in higher education, pp. 123-144, Multilingual Matters, Toronto. 
Otheguy, R., Garcia, O. \& Reid, W., 2015, 'Clarifying translanguaging and deconstructing the named languages: A perspective from linguistics', Applied Linguistics Review 6(3), 281-307. https://doi.org/10.1515/applirev-2015-0014

Pressley, M., 2000, 'What should reading instruction be the instruction of?', in M.L. Kamil, P.B. Mosenthal, P.D. Pearson \& R. Barr (eds.), Handbook of reading research, vol 3, pp. 545-563, Lawrence Erlbaum, Mahwah.

Pressley, M. \& McCormick, C., 1995, Advanced educational psychology, Harcourt Brace, New York

Probyn, M., 2006, 'Language learning science in South Africa', Language and Education 20(5), 391-414.

Rivera, A.J. \& Mazak, C.M., 2016, 'Analysing student perceptions on translanguaging A case study of a Puerto Rican university classroom', How 24(1), 122-138. https:// doi.org/10.19183/how.24.1.312

Saunders, M., Lewis, P. \& Thornhill, A., 2012, Research methods for business students, 6th edn., Pearson Education, Harlow.

Storch, N. \& Wigglesworth, G., 2003, 'Is there a role for the use of the L1 in an L2 setting?', TESOL Quarterly 37(4), 760-770. https://doi.org/10.2307/3588224
Taylor, N. \& Vinjevold, P., 1999, Getting learning right: Report to the President's Education Initiative Research Project, Joint Education Trust, Johannesburg.

Tesch, R., 1991, 'Software for qualitative researchers', in N.G. Fielding \& R.M. Lee, Using computers in qualitative research, Sage, Thousand Oaks.

Underwood, T. \& Pearson, P.D., 2004, 'Teaching struggling adolescent readers what they read', in T.L. Jetton \& J.A. Dole (eds.), Adolescent literacy research practice, pp. 35-61, Guilford, New York.

Wei, L., 2016, 'Epilogue: Multi-competence and the translanguaging instinct', in V. Cook \& L. Wei (eds.), Cambridge handbook of linguistic multi-competence, pp. 533-544, Cambridge University Press, Cambridge.

Williams, C., 1996, 'Secondary education: Teaching in the bilingual situation', in C. Williams, G. Lewis \& C. Baker (eds.), The language policy: Taking stock, pp. 39-78, CAl, Llangefni.

Yamada, K., 2003, 'What prevents ESL/EFL writers from avoiding plagiarism? Analyses of 10 North American college websites', System 31(2), 247-258. https://doi.org/ 10.1016/S0346-251X(03)00023-X 